\title{
A long-term hydrometeorological dataset (1993-2014) of a northern mountain basin: Wolf Creek Research Basin, Yukon Territory, Canada
}

\author{
Kabir Rasouli ${ }^{1,2}$, John W. Pomeroy ${ }^{2}$, J. Richard Janowicz ${ }^{2,3, \dagger}$, Tyler J. Williams ${ }^{2,3}$, and Sean K. Carey ${ }^{4}$ \\ ${ }^{1}$ Department of Geoscience, University of Calgary, Calgary, AB, Canada \\ ${ }^{2}$ Centre for Hydrology, University of Saskatchewan, Saskatoon, SK, Canada \\ ${ }^{3}$ Environment Yukon, Water Resources Branch, Whitehorse, YT, Canada \\ ${ }^{4}$ School of Geography and Earth Sciences, McMaster University, Hamilton, ON, Canada \\ $\dagger$ deceased
}

Correspondence: Kabir Rasouli (kabir.rasouli@usask.ca)

Received: 26 September 2018 - Discussion started: 10 October 2018

Revised: 18 December 2018 - Accepted: 30 December 2018 - Published: 16 January 2019

\begin{abstract}
A set of hydrometeorological data is presented in this paper, which can be used to characterize the hydrometeorology and climate of a subarctic mountain basin and has proven particularly useful for forcing hydrological models and assessing their performance in capturing hydrological processes in subarctic alpine environments. The forcing dataset includes daily precipitation, hourly air temperature, humidity, wind, solar and net radiation, soil temperature, and geographical information system data. The model performance assessment data include snow depth and snow water equivalent, streamflow, soil moisture, and water level in a groundwater well. This dataset was recorded at different elevation bands in Wolf Creek Research Basin, near Whitehorse, Yukon Territory, Canada, representing forest, shrub tundra, and alpine tundra biomes from 1993 through 2014. Measurements continue through 2018 and are planned for the future at this basin and will be updated to the data website. The database presented and described in this article is available for download at https://doi.org/10.20383/101.0113.
\end{abstract}

\section{Introduction}

The availability of hydrometeorological data is limited in northern latitudes in general and in northern mountains in particular. This is because of a sparse monitoring network, harsh weather, and high cost of experiments and instrument maintenance in these environments (Klemeš, 1990). The number of stations that record a complete hydrometeorological dataset in the northern latitudes is limited and declining (Laudon et al., 2017). Wolf Creek Research Basin (WCRB) was established in 1992 to carry out water and climate research and is located in the Yukon Territory, Canada $\left(\approx 61^{\circ} \mathrm{N}\right)$. This basin is operated by Environment Yukon, University of Saskatchewan and McMaster University with support from the Global Water Futures program and provides a long-term dataset for precipitation, air temperature, humidity, wind, radiation, soil moisture, soil temperature, streamflow, and snowpacks at multiple elevations. WCRB includes meteorological stations located from low to high elevation that include a special emphasis on measuring snowpack and snowfall, and discharge gauges to measure streamflow in the main outlet and several tributary streams.

The diversity of the basin, combined with the available long-term comprehensive hydrometeorological data, is responsible for the popularity of WCRB as a site to carry out cold region research by scientists from across Canada and abroad. Road access in summer, local accommodation, a major airport and upper air station in Whitehorse, simple winter logistics, data availability, and ecological diversity make WCRB an ideal location for remote sensing validation and snow modelling activities. WCRB can be used for 


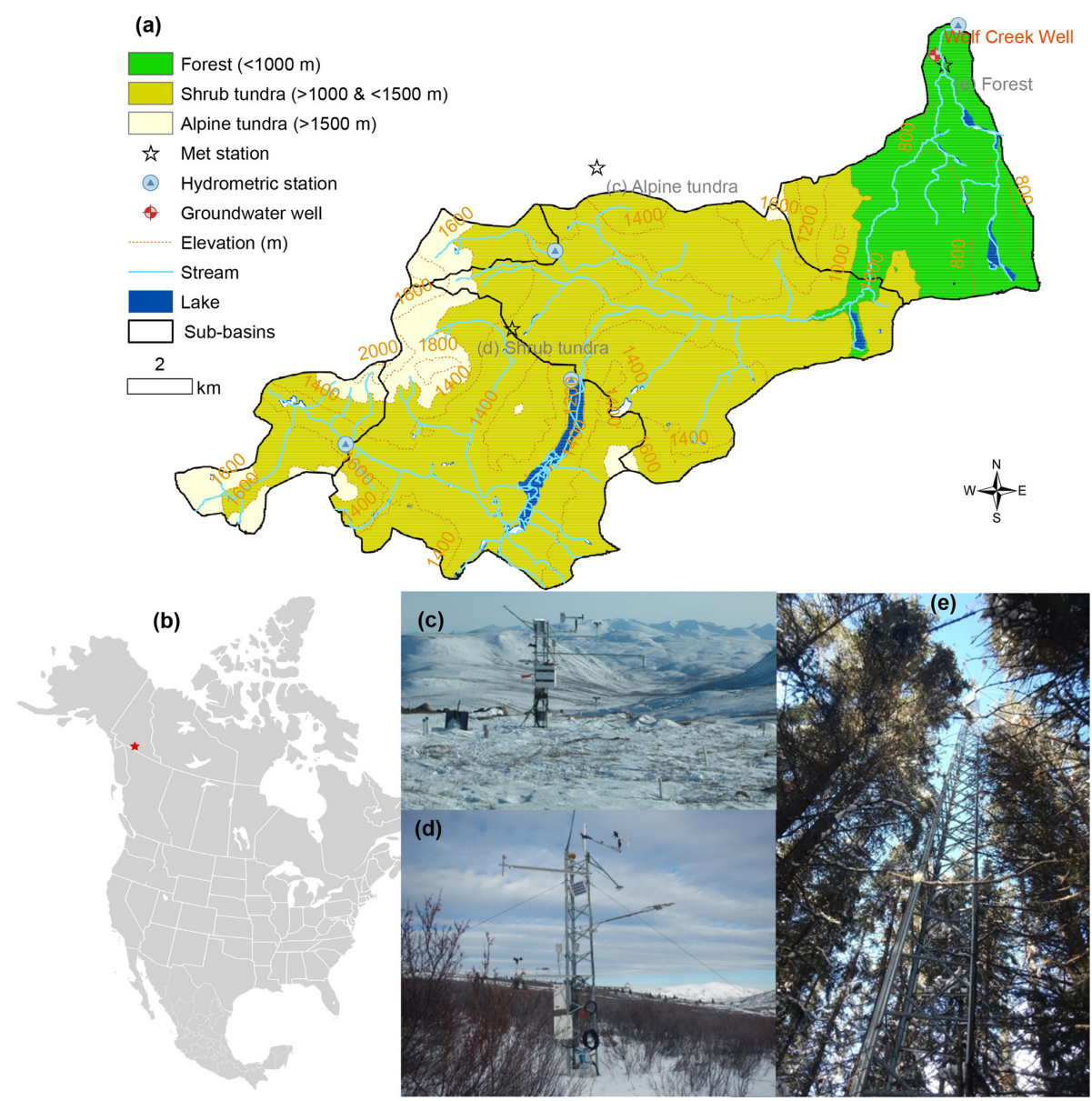

Figure 1. (a) The topography, streams, lakes, land-cover, groundwater well, hydrometric stations, five sub-basins, and three meteorological stations within the Wolf Creek Research Basin, Yukon Territory, Canada, shown in the (b) map of North America. Three meteorological stations represent (c) alpine tundra, (d) shrub tundra-taiga, and (e) forest biomes.

detailed modelling studies as it has been densely monitored, has sufficiently long observation records and has extensive parameter measurements (Pomeroy et al., 1998, 2003, 2006; McCartney et al., 2006; Carey et al., 2007; Dornes et al., 2008; Quinton and Carey, 2008; MacDonald, 2010; Rasouli et al., 2014, 2019; Rasouli, 2017).

\section{Site description}

WCRB is a subarctic headwater basin (Fig. 1) with a long and cold snow season characterized by low precipitation (Fig. 2). The drainage area in this basin is $179 \mathrm{~km}^{2}$ and elevation ranges between 660 and $2080 \mathrm{~m}$ above sea level. The basin is composed of four monitored sub-basins of Upper Wolf Creek, Coal Lake, Granger Creek, and Lower Wolf Creek, one non-monitored sub-basin of Middle Wolf Creek, and also three distinct ecological biomes; alpine tundra $(20 \%)$, shrub tundra and taiga $(58 \%)$, and boreal forest (22\%) (Fig. 1). At the very highest elevations, bare rock, short tundra mosses, and grasses dominate land cover.
Above the treeline, shrub tundra with dwarf birch and willow shrub with heights from $30 \mathrm{~cm}$ to $3 \mathrm{~m}$ occupy the majority of the basin (Torre Jorgenson and Michael Heiner, unpublished report, ABR, Inc., Fairbanks, AK, 2004). The taiga at middle to lower elevations is dominated by shrubs and sparse black spruce woodland. At the lowest elevations are lodgepole pine, white spruce, and trembling aspen forest stands (Francis et al., 1998). Lewkowicz and Ednie (2004) estimate that $43 \%$ of WCRB contains permafrost. The basin physiography is described in detail by Rasouli et al. (2014). Meteorological measurements are taken at three primary stations in each of the biomes (Table 1; Fig. 1) and are described as follows:

1. Alpine tundra station. A windswept, high alpine tundra plateau along the drainage divide at the northern edge just outside of the basin. Vegetation is sparse consisting of moss and lichens, with scattered boulders up to $1 \mathrm{~m}$ tall. Sensors are mounted on a $3 \mathrm{~m}$ tower. Additional snow sensors are a Geonor T200B and Nipher snowfall gauge. 
Table 1. Description of the main meteorological and hydrometric stations within Wolf Creek Research Basin.

\begin{tabular}{lrlll}
\hline Station & Elevation [m] & Latitude [N] & Longitude [W] & Site details \\
\hline (1) Meteorological station & & & & \\
\hline Shrub tundra & 1250 & $60^{\circ} 31.34^{\prime}$ & $135^{\circ} 11.84^{\prime}$ & East-facing moderate slope \\
Alpine & 1615 & $60^{\circ} 34.04^{\prime}$ & $135^{\circ} 08.98^{\prime}$ & Windswept ridge top plateau \\
Forest & 750 & $60^{\circ} 35.76^{\prime}$ & $134^{\circ} 57.17^{\prime}$ & Gently undulating terrain \\
Whitehorse WSO & 706 & $60^{\circ} 44.00^{\prime}$ & $135^{\circ} 05.00^{\prime}$ & At Environment Canada site \\
\hline (2) Hydrometric station & & & & \\
\hline Upper Wolf Creek & 1295 & $60^{\circ} 29.45^{\prime}$ & $135^{\circ} 17.50^{\prime}$ & Drainage area: $14.4 \mathrm{~km}^{2}$ \\
Coal Lake outlet & 1190 & $60^{\circ} 30.61^{\prime}$ & $135^{\circ} 09.74^{\prime}$ & Drainage area: $70.5 \mathrm{~km}^{2}$ \\
Granger Creek & 1312 & $60^{\circ} 32.79^{\prime}$ & $135^{\circ} 11.08^{\prime}$ & Drainage area: $7.6 \mathrm{~km}^{2}$ \\
Alaska Highway & 703 & $60^{\circ} 36.00^{\prime}$ & $134^{\circ} 57.00^{\prime}$ & Drainage area: $179 \mathrm{~km}^{2}$ \\
\hline
\end{tabular}

(3) Groundwater well

\begin{tabular}{|c|c|c|c|c|}
\hline Wolf Creek well & 750 & $60^{\circ} 34.41^{\prime}$ & $134^{\circ} 57.7^{\prime}$ & Water level and temperatures \\
\hline
\end{tabular}

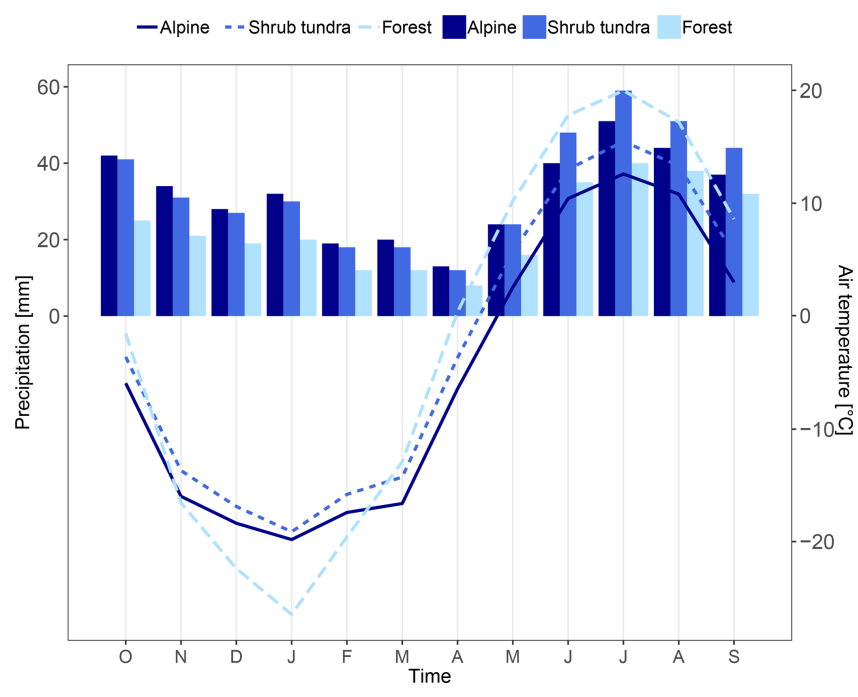

Figure 2. Monthly precipitation and air temperatures at the three sites in Wolf Creek Research Basin averaged over the period of 1993-2014.

2. Shrub tundra-taiga station. An east-facing, moderate hillslope consisting of undulating terrain. Vegetation is tall shrubs $(1-3 \mathrm{~m})$ with sparsely scattered spruce (spaced about $100 \mathrm{~m}$ apart). The presence of strong winds, yet restriction on snow redistribution by shrubs, makes this an ideal site for snowfall wind undercatch studies (Pan et al., 2016; Kochendorfer et al., 2017). Sensors are mounted on a $5.2 \mathrm{~m}$ triangular tower. Additional snow sensors are an OTT Pluvio version 200 and version 400, Geonor T200B, BC Standpipe precipitation gauge, and Nipher snowfall gauge.

3. White spruce forest station. A dense canopy of mature white spruce forest (12-18 m) near the Wolf Creek basin outlet. This is well suited for assessing the effects of forest cover on snow water equivalent (SWE). Sensors are mounted on a $21 \mathrm{~m}$ triangular tower at various heights below, in and above the forest canopy. The tower at this site was relocated in 1996 and caution should be used comparing data before and after the move. Additional snow sensors are a Geonor T200B and a Nipher snowfall gauge.

\section{Geographic descriptors of the drainage basin}

A digital elevation model, or DEM, with a $30 \mathrm{~m}$ cell resolution was prepared by Lawrence Martz (Dept. of Geography, University of Saskatchewan). The DEM, geographic information system files for streamflow gauges, meteorological stations, groundwater well, boundaries of the drainage basin and sub-basins, streamflow tributaries, and lakes are provided (Fig. 1). An image of land-cover is also presented. The land-cover classes were interpreted from Landsat $5 \mathrm{TM}$ supervised image classification in August 1994 by the National Hydrology Research Institute, Environment Canada.

\section{Data description}

Hydrometeorological data are available for WCRB for water years (WYs) from 1994 to 2014 for the three main meteorological stations, one in each primary biome, and four streamflow gauges (Fig. 1; Table 1). In this paper it is assumed that water year starts on 1 October and ends on 30 September. Measurements of snow depth and density along snow survey transects were collected at least monthly by Environment Yukon and university researchers at each of the three meteorological stations. These measurements provide model diagnostic information in each biome 
Table 2. Meteorological data measured at three sites in the basin including variables, climatological water year mean values, current sensors, and measurement height.

\begin{tabular}{|c|c|c|c|c|c|}
\hline Variable & Site & Sensor & $\begin{array}{l}\text { Height/ } \\
\text { depth }[\mathrm{m}]\end{array}$ & Mean & Record period \\
\hline \multirow[t]{4}{*}{$\begin{array}{l}\text { Precipitation } \\
\text { [mm] }\end{array}$} & Alpine & $\begin{array}{l}\text { Texas TE525M TBRG } \\
\text { Geonor T200B }\end{array}$ & 1.87 & 384 & $\begin{array}{l}\text { 1993-2014 } \\
\text { daily }\end{array}$ \\
\hline & Shrub tundra & $\begin{array}{l}\text { Texas TE525M TBRG } \\
\text { Standpipe } \\
\text { OTT Pluvio version } 200 \\
\text { Geonor T200B }\end{array}$ & 4.76 & 403 & $\begin{array}{l}\text { 1993-2014 } \\
\text { daily }\end{array}$ \\
\hline & Forest & Texas TE525M TBRG & 21.34 & 278 & 1993-2014 \\
\hline & & Geonor T200B & 1.75 & & daily \\
\hline \multirow{6}{*}{$\begin{array}{l}\text { Air temper- } \\
\text { ature }\left[{ }^{\circ} \mathrm{C}\right] \text { and } \\
\text { humidity }[\%]\end{array}$} & Alpine & Vaisala HMP35CF & 2.05 & $-3.5 \& 78$ & 1993-2014 \\
\hline & & HM45C212 (post-2005) & 2.05 & & hourly \\
\hline & Shrub tundra & Vaisala HMP35CF & 2.6 & $-1.9 \& 77$ & $1993-2014$ \\
\hline & & HMP45-212 (post-2005) & 2.6 & & hourly \\
\hline & Forest & Vaisala HMP35CF & 21.34 & $-1.4 \& 75$ & 1993-2014 \\
\hline & & HMP45-212(post-2007) & 21.34 & & hourly \\
\hline \multirow{6}{*}{$\begin{array}{l}\text { Wind speed } \\
{\left[\mathrm{m} \mathrm{s}^{-1}\right] \&} \\
\text { direction }[-]\end{array}$} & Alpine & NRG 40 cup anemometer & 2.75 & $3.6(\mathrm{SE})$ & 1993-2014 \\
\hline & & NRG 200P & 2.75 & & hourly \\
\hline & Shrub tundra & NRG 40 cup anemometer & 4.6 & $1.8(\mathrm{SW})$ & 1993-2014 \\
\hline & & RM Young 5103 & 4.98 & & hourly \\
\hline & Forest & NRG 40 cup anemometer & 19.82 & $1.4(\mathrm{SE})$ & $1993-2014$ \\
\hline & & RM Young 5103 & 20 & & hourly \\
\hline \multirow{6}{*}{$\begin{array}{l}\text { Net radiation } \\
{\left[\mathrm{W} \mathrm{m}^{-2}\right]}\end{array}$} & Alpine & REBS Q6.0 & 1.68 & 40 & $1993-2014$ \\
\hline & & NR-Lite (post 2004) & 1.68 & & hourly \\
\hline & Shrub tundra & REBS Q6.0 & 3.10 & 61 & $1993-2014$ \\
\hline & & NR-Lite (post 2006) & 3.18 & & hourly \\
\hline & Forest & REBS Q6.0 & 19.82 & Above & $1993-2014$ \\
\hline & & NR-Lite (post 2006) & 19.82 & canopy,77 & hourly \\
\hline \multirow{6}{*}{$\begin{array}{l}\text { Solar } \\
\text { radiation } \\
{\left[\mathrm{W} \mathrm{m}^{-2}\right]}\end{array}$} & Alpine & LiCor Li200S & in: 2.93 & in: 231 & $1993-2014$ \\
\hline & & Kipp \& Zonen CMP3-L (post 2005) & out: 1.69 & out: 95 & hourly \\
\hline & Shrub tundra & LiCor Li200S & in: 4.8 & in: 203 & $1995-2014$ \\
\hline & & Kipp \& Zonen CMP3-L (post 2006) & out: 4.4 & out: 59 & hourly \\
\hline & Forest & LiCor Li200S & in: 20.43 & in: 234 & $1995-2014$ \\
\hline & & Kipp \& Zonen CMP3-L (post-2007) & out: 14.33 & out: 16 & hourly \\
\hline \multirow{3}{*}{$\begin{array}{l}\text { Ground heat } \\
\text { flux } \\
{\left[\mathrm{W} \mathrm{m}^{-2}\right]}\end{array}$} & Alpine & REBS HFT3 & -0.08 & 2.65 & $\begin{array}{l}\text { 1994-2013 } \\
\text { hourly }\end{array}$ \\
\hline & Shrub tundra & REBS HFT3 & -0.11 & 1.04 & $\begin{array}{l}1993-2013 \\
\text { hourly }\end{array}$ \\
\hline & Forest & REBS HFT3 & -0.16 & -0.65 & $\begin{array}{l}\text { 1994-2013 } \\
\text { hourly }\end{array}$ \\
\hline
\end{tabular}

(Pomeroy and Granger, 1999). High quality meteorological measurements of hourly air temperature, relative humidity, rainfall, wind speed, incoming and outgoing shortwave radiation, net radiation, soil heat flux, soil moisture and temperature, and daily precipitation observations for three stations (Table 2); and hydrological measurements of hourly streamflow data recorded by four gauges, snow water equivalent, snow depth, and water level at one groundwater well (Table 3) are presented for the period of 1993-2014 in this paper. Tables 2 and 3 list the sensors measuring meteorology, streamflow, soil parameters, groundwater, and snow at the three sites in WCRB and provide the height or 
Table 3. Hydrological data measured in the basin including variables, climatological water year mean values, current sensors, and measurement height. Negative heights show below ground depths.

\begin{tabular}{|c|c|c|c|c|c|}
\hline Variable & Site & Sensor & Height/depth [m] & Mean & Record period \\
\hline \multirow{3}{*}{$\begin{array}{l}\text { Snow water } \\
\text { equivalent } \\
{[\mathrm{mm}]}\end{array}$} & Alpine & Mt. Rose sampler & - & 64 & $\begin{array}{l}\text { 1993-2014 } \\
\text { monthly }\end{array}$ \\
\hline & Shrub tundra & Mt. Rose sampler & - & 90 & $\begin{array}{l}\text { 1993-2014 } \\
\text { monthly }\end{array}$ \\
\hline & Forest & Mt. Rose sampler & - & 37 & $\begin{array}{l}\text { 1993-2014 } \\
\text { monthly }\end{array}$ \\
\hline \multirow[t]{3}{*}{$\begin{array}{l}\text { Snow depth - } \\
\text { April [mm] }\end{array}$} & Alpine & $\begin{array}{l}\text { CSI UDG01 } \\
\text { UDG01 (post-2005) }\end{array}$ & 1.65 & 20 & $\begin{array}{l}\text { 1993-2014 } \\
\text { monthly }\end{array}$ \\
\hline & Shrub tundra & $\begin{array}{l}\text { CSI UDG01 } \\
\text { SR-50 (post-2005) }\end{array}$ & 1.67 & 52 & $\begin{array}{l}\text { 1993-2014 } \\
\text { monthly }\end{array}$ \\
\hline & Forest & $\begin{array}{l}\text { CSI UDG01 } \\
\text { SR-50 (post-2007) }\end{array}$ & 1.41 & 12 & $\begin{array}{l}\text { 1993-2014 } \\
\text { monthly }\end{array}$ \\
\hline \multirow[t]{3}{*}{$\begin{array}{l}\text { Soil moisture } \\
{\left[\mathrm{m}^{3} \mathrm{~m}^{-3}\right]}\end{array}$} & Alpine & CSI CS615 TDR & $-0.05,-0.15$ & $0.12,0.16$ & $\begin{array}{l}\text { 1997-2013 } \\
\text { hourly }\end{array}$ \\
\hline & Shrub tundra & CSI CS615 TDR & $\begin{array}{l}-0.05,-0.15,-0.30 \\
-0.80\end{array}$ & $\begin{array}{lll}0.19, & 0.20, & 0.20, \\
0.18 & & \end{array}$ & $\begin{array}{l}\text { 1996-2013 } \\
\text { hourly }\end{array}$ \\
\hline & Forest & CSI CS615 TDR & $\begin{array}{l}-0.05,-0.15,-0.30 \\
-0.80\end{array}$ & $\begin{array}{l}0.07, \quad 0.10, \quad 0.11, \\
0.14\end{array}$ & $\begin{array}{l}1997-2013 \\
\text { hourly }\end{array}$ \\
\hline \multirow[t]{3}{*}{$\begin{array}{l}\text { Soil tempera- } \\
\text { ture }\left[{ }^{\circ} \mathrm{C}\right]\end{array}$} & Alpine & YSI 40328 & $\begin{array}{l}0,-0.03,-0.05 \\
-0.15\end{array}$ & $\begin{array}{l}-0.7,-1.2,-1.6, \\
-2.7\end{array}$ & $\begin{array}{l}\text { 1997-2013 } \\
\text { hourly }\end{array}$ \\
\hline & Shrub tundra & YSI 40328 & $\begin{array}{l}-0.05,-0.10,-0.15 \\
-0.30,-0.80\end{array}$ & $\begin{array}{l}1.7,1.3,1.3,1.2, \\
1.9\end{array}$ & $\begin{array}{l}\text { 1996-2013 } \\
\text { hourly }\end{array}$ \\
\hline & Forest & YSI 40328 & $\begin{array}{l}0,-0.05,-0.15 \\
-0.30,-0.80\end{array}$ & $\begin{array}{l}-1.2,-0.1,-0.2, \\
0.2,0.2,0.9\end{array}$ & $\begin{array}{l}1997-2013 \\
\text { hourly }\end{array}$ \\
\hline $\begin{array}{l}\text { Groundwater } \\
\text { level }[\mathrm{m}]\end{array}$ & Forest & $\begin{array}{l}\text { HOBO (2001-2007) } \\
\text { Solinst (2008-2014) baro } \\
\text { pressure loggers }\end{array}$ & - & -16.45 & $\begin{array}{l}2001-2014 \\
\text { hourly }\end{array}$ \\
\hline \multirow[t]{4}{*}{$\begin{array}{l}\text { Streamflow } \\
{\left[\mathrm{m}^{3} \mathrm{~s}^{-1}\right]}\end{array}$} & $\begin{array}{l}\text { Alaska } \\
\text { Highway }\end{array}$ & Various Instrumentation & - & 0.775 & $\begin{array}{l}1993-2014 \\
\text { hourly }\end{array}$ \\
\hline & Coal Lake & Logger level & - & 0.336 & $\begin{array}{l}\text { 1994-2012 } \\
\text { hourly }\end{array}$ \\
\hline & $\begin{array}{l}\text { Upper Wolf } \\
\text { Creek }\end{array}$ & Logger level & - & 0.075 & $\begin{array}{l}\text { 1994-2011 } \\
\text { hourly }\end{array}$ \\
\hline & $\begin{array}{l}\text { Granger } \\
\text { Creek }\end{array}$ & Logger level & - & 0.098 & $\begin{array}{l}\text { 1998-2012 } \\
\text { hourly }\end{array}$ \\
\hline
\end{tabular}

depth of the instruments, long-term climatological averages, and periods of observation record. All stations record data at $30 \mathrm{~min}$ intervals, but are reported hourly (except for precipitation data that are reported daily) in this paper with continuous records for several parameters at the main stations. Hourly precipitation data have not been collected until recently when the Geonor T200B precipitation gauges were installed in the basin. In future, hourly data for precipitation will be uploaded to the database, which can be useful for determining precipitation phases and weather patterns. We will continuously update the database with recently recorded data. All stations use Campbell Scientific data loggers and data have been transmitted using cellular modems and spread-spectrum radios since 2016.

Precipitation has been measured by tipping bucket rain gauges, unshielded BC-style Standpipe precipitation gauges, Nipher-shielded Meteorological Service of Canada (MSC) snowfall, and, recently, Alter-shielded OTT Pluvio and Geonor gauges. OTT Pluvio (since 2013) and Standpipe gauges were installed only at the shrub tundra site. Geonor gauges were installed in 2007 at the forest site and in 2010 at the shrub tundra and alpine sites. The Campbell SR-50 ultrasonic snow depth sensors can contain substantial noise which is in part due to vegetation, falling snow particles, 
and movement of the sensor. As mentioned, the forest tower relocated in June 1996, so the first few years of data are similar but not directly comparable to the new site. Snow surveys have been carried out once a month and snow depth, snow density, and snow water equivalent (SWE) data have been collected over the period of 1994-2014 at three traditional snow survey sites at the alpine, shrub tundra, and forest sites. Each has a 25 point transect for snow depth. Snow density is measured only at 5 out of 25 points. A relationship between snow depth and snow density was used to estimate density across the transect and then measured and estimated snow density values were used to estimate SWE. Spatial variability of snow depth is higher than snow density. In addition, snow depth measurements are less timeconsuming than density measurements, thus determining SWE with a small sample of density measurements and a large sample of depth measurements can represent average SWE across the transect with more reasonable accuracy.

The water level at streams was monitored continuously from ice thaw in early May to freeze-up in early October. Discharge measurements involving manual stream velocity measurements throughout the year are taken approximately once a month at Upper Wolf Creek, Coal Lake outlet, and Wolf Creek at the Alaska Highway. Solinst leveloggers are currently used for measuring level at the four hydrometric stations (Fig. 1). Other instruments that were previously used for measuring water level and streamflow are HOBO U20001-04 pressure transducers, OTT Thalimedes shaft encoders and Leupold and Stevens A-71 Strip Charts. The Alaska Highway hydrometric station has the most field visits due to ease of access, has received the most attention due to its importance as the basin outlet, and has bridge access for the measurement of exceptionally high flows. As a result, it has the highest quality discharge observations in the basin. However, at very high flows, the channel is not ideal, particularly on the left bank where a small stream enters the creek adjacent to the gauging well. Additionally, there is uncertainty with the staff gauge reading at high flows, due to hydraulic jumps. At the highest of flows, it is best to rely on the instrument gauge readings. The Coal Lake station is located in a location with good channel geometry for rating development, yet has been challenging to instrument early to capture high flows. Historically, at least one and possibly more outburst flood events have occurred which produce high discharge early in the season. At the very highest water levels experienced at the station, the site is susceptible to flooding. Granger Creek is a steep, narrow, rough, and turbulent creek that is not ideal for velocity-area measurements or rating curve development, and so there is likely considerable error associated with the site. A very high water discharge measurement has never been made at the site, and benchmarks have only been in use since 2012 so water level data are not transferable from older data. The channel is well controlled so that flooding is not an issue. The flashy nature of high water at Granger Creek also makes it difficult to observe snowmelt induced peak flows, which generally occur towards late in the day. The Upper Wolf Creek station was partially buried by a debris flow caused by an intensive convective storm and flood in the summer of 2013 and has been inactive since then. The site has historically been a source of difficulty as it has already been relocated once due to beaver activity. It is difficult to find an adequate control at Upper Wolf Creek, with high flows often overtopping the bank and making it difficult to measure high water.

Volumetric soil moisture (unfrozen water content) and soil temperature were recorded every $30 \mathrm{~min}$ over the period of 1996-2014 at the meteorological stations in soil profiles at $0.05,0.15,0.30,0.80 \mathrm{~m}$ depths (Table 3). A groundwater well was installed in 2001, approximately $14 \mathrm{~km}$ south of downtown Whitehorse, Yukon Territory (Fig. 1). It is an open-hole observation well on bedrock with $48.8 \mathrm{~m}$ depth and $15.24 \mathrm{~cm}$ diameter and an estimated production capacity of $0.6 \mathrm{~L} \mathrm{~s}^{-1}$. Water level depth and temperature have been monitored hourly since 2001 at this well.

\section{Data processing and adjustments}

Data loss has been a common problem during the early winter due to power failure at stations with the onset of darkness and cold weather. The Standpipe gauge at the shrub tundra site is a pressure sensing precipitation gauge that broadcasts real-time data every $3 \mathrm{~h}$. Niphergauge solid precipitation measurements were corrected using a wind undercatch correction equation (Goodison et al., 1998) with wind speeds measured from nearby gaugeheight anemometers. Precipitation data with poor quality were removed and gaps in data were filled by establishing regression equations for meteorological variables between each of the three meteorological stations and the Whitehorse Weather Service Office (WSO) station, which is located $13 \mathrm{~km}$ from WCRB. The equations to fill the gaps in precipitation and to correct for the wind undercatch are listed in Table 4. Precipitation data from the Whitehorse Airport and Whitehorse Riverdale stations were taken to fill the gaps primarily in the WY of 1996-1997. Changes in elevation rather than distance between stations are assumed to be responsible for the meteorological variation in this study basin. First, total daily precipitation was separated to snowfall and rainfall phases using a method developed by Harder and Pomeroy (2013), in which psychrometric energy balance of the falling hydrometeors was calculated and used to estimate precipitation phase based on the turbulent transfer equations of blowing snow sublimation (Pomeroy and Gray, 1995). Then, the snowfall proportion of precipitation was corrected for wind undercatch in each site. When data were missing, precipitation at the shrub tundra or alpine station was estimated solely based on the Whitehorse WSO measurements. Whitehorse WSO 
Table 4. Equations used to fill the gaps and correct the erroneous values in precipitation, relative humidity, and net radiation in the three stations representing forest, shrub tundra, and alpine biomes in the Wolf Creek Research Basin.

\begin{tabular}{lll}
\hline Variable & Equation & No. \\
\hline Snowfall & $S_{\mathrm{N}}^{\mathrm{sh}}=1.339 S_{\mathrm{S}}^{\mathrm{sh}} \quad R^{2}=0.998$ \\
Snowfall & $S_{\mathrm{N}}^{\mathrm{sh}}=1.427 S_{\mathrm{N}}^{\mathrm{WH}} \quad R^{2}=0.997$ \\
Rainfall & $R_{\mathrm{S}}^{\mathrm{sh}}=1.333 R_{\mathrm{N}}^{\mathrm{WH}} \quad R^{2}=0.988$ \\
Snowfall & $S_{\mathrm{N}}^{\mathrm{A}}=0.926 S_{\mathrm{N}}^{\mathrm{sh}} \quad R^{2}=0.999$ \\
Rainfall & $R_{\mathrm{S}}^{\mathrm{sh}}=1.0394 R_{\mathrm{G}}^{\mathrm{A}} \quad R^{2}=0.996$ \\
Rainfall & $R_{\mathrm{G}}^{\mathrm{sh}}=1.0036 R_{\mathrm{S}}^{\mathrm{sh}} \quad R^{2}=0.998$ \\
Snowfall catch ratio & $\mathrm{CR}=100-2.02 U-0.387 U^{2}$ \\
Relative humidity & $\mathrm{RH}$ Corrected $=a \cdot \mathrm{RH}_{\mathrm{raw}}^{2}+b \cdot \mathrm{RH}_{\mathrm{raw}}+1$ \\
& $\left.a=\frac{99}{(\mathrm{RH}}+1\right)$ \\
& $b=0.986-70 a$ \\
Net radiation & $\mathrm{Rn}_{\text {corrected }}=\left(\begin{array}{l}1.0627 \mathrm{Rn}_{\mathrm{obs}} \\
1.0079 \mathrm{Rn}_{\mathrm{obs}} \quad \mathrm{Rn}_{\mathrm{obs}}>0\end{array}\right)$ \\
Net radiation & $\mathrm{Rn}_{\text {corrected }}=\frac{A}{1-\frac{0.054 \times 0.11 U}{0.054+0.11 U}} \cdot \mathrm{Rn}_{\mathrm{obs}}$
\end{tabular}

snowfall measurements are collected using a Nipher gauge and require appropriate wind correction using WSO wind speed measurements. Whitehorse WSO precipitation was assumed equal to precipitation at the forest site because of their proximity and similar elevations. Using available monthly totals, a relationship was found between cumulative snowfall at the Standpipe $\left(S_{\mathrm{S}}^{\mathrm{sh}}\right)$ and the Nipher gauges to calculate "Nipher equivalent" snowfall $\left(S_{\mathrm{N}}^{\mathrm{sh}}\right)$ at the shrub tundra site as in Eq. (1). When Standpipe data were not available, a relationship between Nipher equivalent cumulative precipitation at the shrub tundra site and the Nipher precipitation at the Whitehorse WSO site $\left(S_{\mathrm{N}}^{\mathrm{WH}}\right)$ was used as in Eq. (2). The snowfall data at the shrub tundra site also require a Nipher wind undercatch correction. To estimate missing rainfall data in the shrub tundra site and the Standpipe gauge, a relationship between cumulative rainfall at the Standpipe gauge $\left(R_{\mathrm{S}}^{\mathrm{sh}}\right)$ and rainfall at the Whitehorse WSO site was used as in Eq. (3). To estimate missing snowfall at the alpine site, a relationship was used for uncorrected cumulative snowfalls between the alpine and shrub tundra Nipher gauges based on available monthly data as in Eq. (4). This equation can also be applied to the calculated daily "Nipher shrub tundra equivalent" in Eq. (1). To estimate missing rainfall data at the alpine site, the relationship between cumulative rainfall at the alpine Geonor $\left(R_{\mathrm{G}}^{\mathrm{A}}\right)$ and the shrub tundra Standpipe (Eq. 5) was applied to the daily rainfall data calculated or measured for shrub tundra as in Eq. (3). A relationship between cumulative rainfall data recorded at the shrub tundra Standpipe and Geonor gauges was found as in Eq. (6).

For undercatch correction, gaps in wind speed data $(U)$ also were filled by interpreting from other stations based on best fit linear equations. The catch ratio (CR) for the Nipher gauges was calculated from Eq. (7), in which wind speed in $\mathrm{ms}^{-1}$ is measured at the Nipher gauge height (Goodison et al., 1998). In order to calculate wind speed at gauge height, roughness lengths of $0.001 \mathrm{~m}$ at the alpine and $0.1 \mathrm{~m}$ at the shrub tundra were used (Pomeroy et al., 1997). Regression equations were used to fill the gaps in other meteorological variables in the three stations representing forest, shrub tundra, and alpine biomes in WCRB. The regression equations for air temperature, relative humidity, and wind speed were provided in Table 5. Air temperature data have undergone a thorough quality control process. This included comparing air temperature among the three sites to look for unrealistic differences. Where available, air temperatures were also compared between multiple measurements made at the same site. The gaps in hourly air temperature data that were between $6 \%$ and $13 \%$ of the total data were also filled by regressions established between hourly temperatures at the three sites in WCRB (Table 5). 
Table 5. Regression equations used to fill the gaps in meteorological variables in the three stations representing forest, shrub tundra, and alpine biomes in the Wolf Creek Research Basin.

\begin{tabular}{|c|c|c|c|c|c|}
\hline $\begin{array}{l}\text { Station } \\
\text { Dependent }\end{array}$ & $\begin{array}{l}\text { Station } \\
\text { Independent }\end{array}$ & $\begin{array}{l}\text { Regression } \\
\text { equation }\end{array}$ & $\begin{array}{r}\text { Air } \\
\text { temperature } \\
{\left[{ }^{\circ} \mathrm{C}\right]}\end{array}$ & $\begin{array}{r}\text { Relative } \\
\text { humidity } \\
{[\%]}\end{array}$ & $\begin{array}{r}\text { Wind } \\
\text { speed } \\
{\left[\mathrm{m} \mathrm{s}^{-1}\right]}\end{array}$ \\
\hline \multirow[t]{7}{*}{ Forest } & \multirow[t]{3}{*}{ Shrub tundra } & slope & 1.18 & 0.80 & 0.29 \\
\hline & & intercept & 0.91 & 12.64 & 0.89 \\
\hline & & $R^{2}$ & 0.89 & 0.55 & 0.22 \\
\hline & \multirow[t]{3}{*}{ Alpine } & slope & 1.20 & 0.75 & 0.14 \\
\hline & & intercept & 2.74 & 11.84 & 0.88 \\
\hline & & $R^{2}$ & 0.84 & 0.48 & 0.16 \\
\hline & Data available $(\%)$ & & 94 & 93 & 76 \\
\hline \multirow[t]{7}{*}{ Shrub tundra } & \multirow[t]{3}{*}{ Forest } & slope & 0.75 & 0.69 & 0.77 \\
\hline & & intercept & -0.85 & 24.21 & 0.75 \\
\hline & & $R^{2}$ & 0.89 & 0.55 & 0.22 \\
\hline & \multirow[t]{3}{*}{ Alpine } & slope & 1.02 & 0.87 & 0.35 \\
\hline & & intercept & 1.59 & 5.25 & 0.59 \\
\hline & & $R^{2}$ & 0.95 & 0.74 & 0.36 \\
\hline & Data available (\%) & & 89 & 90 & 82 \\
\hline \multirow[t]{7}{*}{ Alpine } & \multirow[t]{3}{*}{ Forest } & slope & 0.69 & 0.64 & 1.12 \\
\hline & & intercept & -2.36 & 32.75 & 2.12 \\
\hline & & $R^{2}$ & 0.84 & 0.48 & 0.16 \\
\hline & \multirow[t]{3}{*}{ Shrub tundra } & slope & 0.93 & 0.85 & 1.01 \\
\hline & & intercept & -1.59 & 16.14 & 1.84 \\
\hline & & $R^{2}$ & 0.95 & 0.74 & 0.36 \\
\hline & Data available $(\%)$ & & 87 & 87 & 78 \\
\hline
\end{tabular}

When data were missing for a few hours, an interpolation between air temperatures before and after the gap was used.

The relative humidity $(\mathrm{RH})$ data at the alpine site had periods of $\mathrm{RH}>100 \%$ prior to correction. For the first few years of the archive, the data often exceeded 100 . From 1995-2005 the peak RH being recorded gradually increased each year. Starting in September 2005, the sensor was replaced with a new version, and data quality improved, rarely exceeding $100 \%$. From 2010 to 2018 the data were almost entirely below $100 \%$. For a few years between 1998 and 2000, there was also a second RH sensor at the alpine site. This sensor confirmed that the main tower RH sensor was in fact providing values that were too high, but also showed that for low RH values it was also reporting values that were too low. As such, an equation was developed to reduce the variation of the raw data $\left(\mathrm{RH}_{\text {raw }}\right)$ using a second order polynomial as in Eq. (8) in Table 4 in which $a$ and $b$ are constant values related to the peak measured relative humidity $\left(\mathrm{RH}_{\text {raw,max }}\right)$. The $\mathrm{RH}$ data at the shrub tundra and forest sites, which have similar patterns to the alpine site, were quality-controlled and unreasonable data were corrected.

The Radiation and Energy Balance Systems (REBS) instrument measurements for net radiation $(\mathrm{Rn})$ require wind speed corrections and are now understood to have considerable measurement uncertainty. REBS were operational prior to 2006. When wind speed (U) data were not available a generic equation - such as Eq. (9) - was applied and when wind speed data were available Eq. (10) was used (Table 4). In all cases, the propeller anemometers were the first choice used for wind speed, and if these were not available, cup anemometers were used. The NR-Lite2 instruments also required a post correction in some cases. This correction is only required when wind speed exceeded $5 \mathrm{~m} \mathrm{~s}^{-1}$ (Eq. 11). After the installation of the CR1000 data loggers in 2013, this correction equation for the NR-Lite2 was written directly into the program and therefore postcorrections are no longer required. The original data were not destroyed with any of these corrections, so "uncorrected" net radiation data prior to wind corrections are available for all sites. Shortwave radiation data were collected initially by LiCor Li200S and after 2005 by Kipp-Zonen CMP3-L sensors; these data needed to be cleaned to change night-time values to zero, but in other cases the data still have small non-zero values. The CR1000 program now automatically changes negative radiation values to zero, but there can still be small erroneous positive values. Snow or hoarfrost can frequently build up on the solar radiation sensors in midwinter when wind speeds are low. 
Snow depth data from the Campbell Scientific Canada SR50 ultrasonic depth sounder are adjusted to compensate for the effect of temperature on the speed of sound and require a further quality control to smooth out half-hour data and remove the most obviously erroneous data due to precipitation, blowing snow, and movement of the gauge or growth of vegetation under the gauge (vegetation height can be misinterpreted as snow depth). Data were shifted up or down to ensure that the snow depth started and ended the snow-covered period at 0 , and albedo increases were used to help identify the snow-covered periods. Except for cases with erroneous data, outgoing and incoming shortwave radiations derived from the radiometers were temporally consistent, which were used to obtain changes in the albedo and snow cover. These corrections have been applied to the entire historical record for all sites and have produced useable datasets at a daily time scale. The snow depth sites, however, have occasionally been disturbed in the past by people standing too close to or falling under the sensor, which adds uncertainty.

Corrections were required to account for differences in soil moisture data over time, some of which are likely due to changes in data loggers or programs. There was a shift in soil moisture values at the forest site after 2005 at depths of 0.3 and $0.8 \mathrm{~m}$ below ground surface. This shift was corrected and the data recorded before 2005 were corrected to match with the range of the data recorded after 2005. Neither the shrub tundra nor alpine pits have had this correction.

\section{Monthly climatological averages}

The long-term monthly averages are presented over the 22year period in this section. Precipitation reaches maximum $59 \mathrm{~mm}$ at the shrub tundra site in July and minimum $8 \mathrm{~mm}$ in April at the forest site (Fig. 2). Precipitation maxima fall as rain in summer months. The rainfall ratio, which is defined as the ratio of annual rainfall to total annual precipitation, decreases with elevation: 0.61 at the forest site (750 $\mathrm{m}$ a.s.1.), 0.56 at the shrub tundra site $(1250 \mathrm{~m}$ a.s.l.), and 0.51 at the alpine site (1615 m a.s.1.). The long-term climatological averages show that air temperature is below the freezingpoint for 7 months at all three sites in the WCRB. The intermonthly variation of air temperature is the largest in the forest site which reaches $-18^{\circ} \mathrm{C}$ in January and $13.6^{\circ} \mathrm{C}$ in July (Fig. 2). The relative humidity is the lowest in April and May at the forest site and the highest in October at the alpine site in WCRB (Fig. 3). The recorded wind speed increases with elevation and reaches the maximum value of $35 \mathrm{~m} \mathrm{~s}^{-1}$ at the alpine site in WCRB over 1993-2014. The prevailing wind direction is southeasterly in the alpine site and above canopy in the forest site and southwesterly in the shrub tundra site (Fig. 4). Maximum wind speed reaches $8 \mathrm{~m} \mathrm{~s}^{-1}$ above canopy in the forest site (Fig. 4c), which is the lowest amongst the three sites. The second prevailing

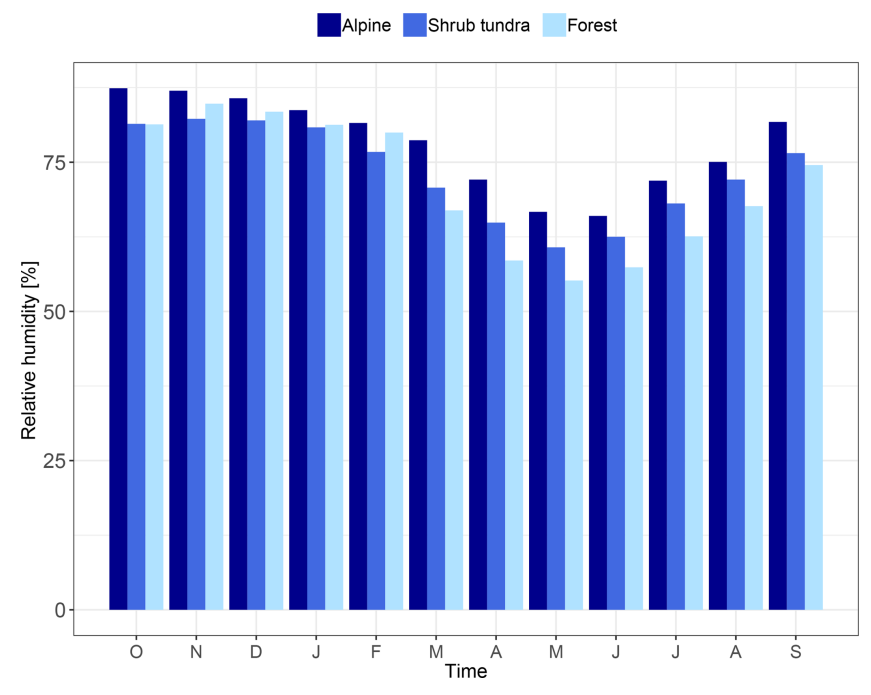

Figure 3. Water year cycle of relative humidity at the three sites in Wolf Creek Research Basin averaged over the period of 1993-2014.

wind direction is northwesterly at all three sites in WCRB (Fig. 4). Figure 5 shows the annual cycle of streamflow at the Alaska Highway and Coal Lake gauges. Streamflow records show the lowest rates in March and then rise sharply in both gauges and reach their peak values in July. Monthly patterns of streamflow at Coal Lake as a sub-basin and at the Alaska Highway as an outlet of the WCRB are almost the same. Figure 5 shows the annual cycle of water level in the groundwater well. On average, the water level drops to $16.2 \mathrm{~m}$ below ground surface in April and rises to its maximum level, $15.87 \mathrm{~m}$ below ground surface in August and September. Figure 6a shows the annual cycle of the soil unfrozen water content at the shrub tundra site at the top $1 \mathrm{~m}$ soil depth. Soils are dry in winter and soil unfrozen water content is below 0.15 in all of the soil layers in a soil profile with $1 \mathrm{~m}$ depth. Soil moisture increases rapidly in April and reaches its maximum value of $0.5 \mathrm{~m}^{3} \mathrm{~m}^{-3}$ in May at the top $0.2 \mathrm{~m}$ soil depth. Soils freeze from November to April down to $0.7 \mathrm{~m}$ below ground surface and soil temperature reaches $8{ }^{\circ} \mathrm{C}$ in July and August (Fig. 6b). Soil temperatures at the top $0.20 \mathrm{~m}$ soil layer vary dramatically with air temperature seasonality. Soil temperatures at lower layers show a delay in response to air temperature variations.

\section{Example of data use}

Data over the period of 1993-2011 were used by Rasouli et al. (2014, 2019) and Rasouli (2017) to investigate the change in mountain snow and runoff regimes under simulated warmer and wetter conditions in an uncertainty framework. Future projections from 11 of the regional climate models for the A2 scenario of the Special Report on Emissions Scenarios (SRES) for the period 2041-2070 were 


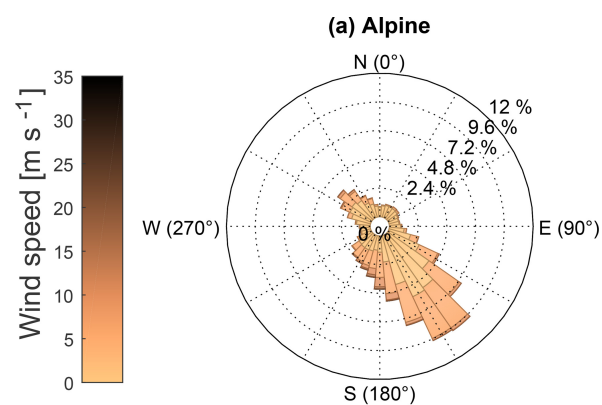

(b) Shrub tundra

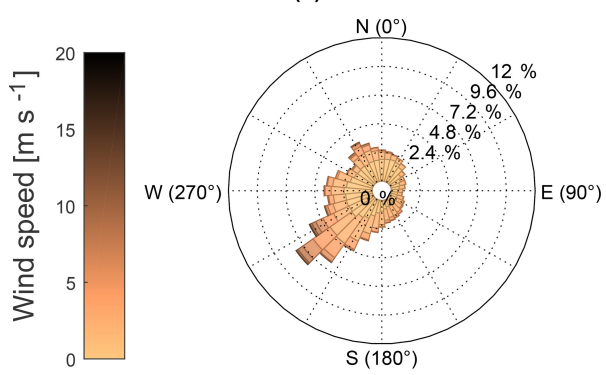

(c) Forest - above canopy

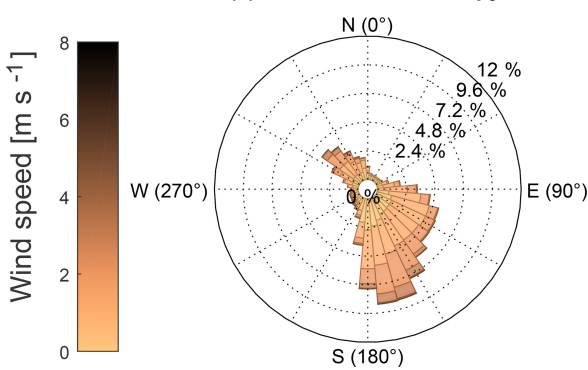

Figure 4. Wind speed and direction at the three sites in Wolf Creek Research Basin, averaged over the period of 1993-2014.

used to perturb records of observations of temperature and precipitation in WCRB.

\section{Data availability}

The database presented and described in this article is available for download from Federated Research Data Repository at https://doi.org/10.20383/101.0113 (Rasouli et al., 2018). Data at the different stations are provided in separated files in csv format. The DEM of the study area $\left(179 \mathrm{~km}^{2}\right)$ at $30 \mathrm{~m}$ resolution is also provided in NAD_1983_UTM_Zone_10N coordinates. New data will be added in the database on a yearly basis and made available to the community.

\section{Final remarks}

The data from the Wolf Creek Research Basin have contributed significantly to our understanding of snow and runoff

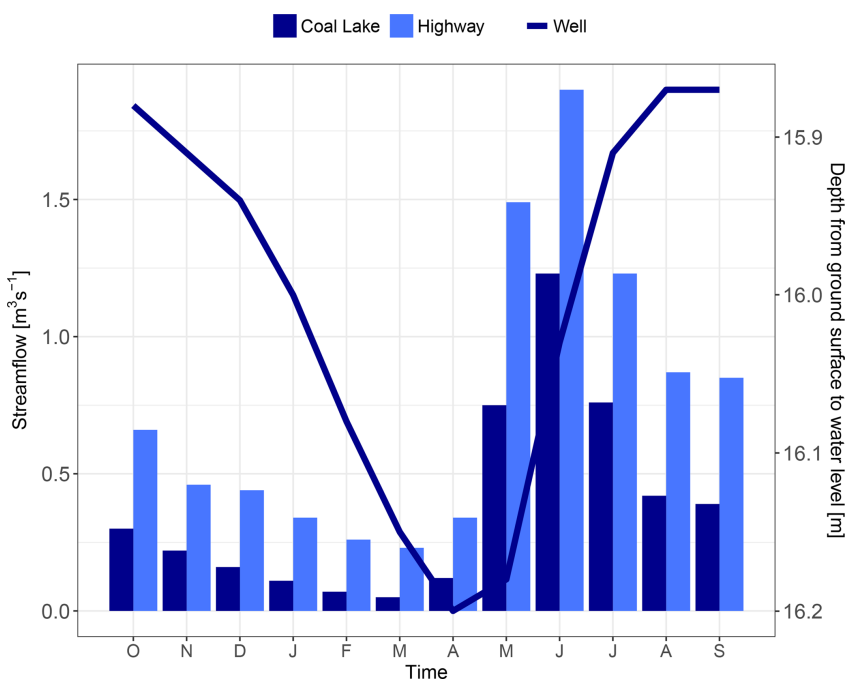

Figure 5. Water year cycle of streamflow at two Alaska Highway and Coal lake gauges, along with water levels in the groundwater well located in the forest biome within the Wolf Creek Research Basin.

(a) Soil unfrozen water content

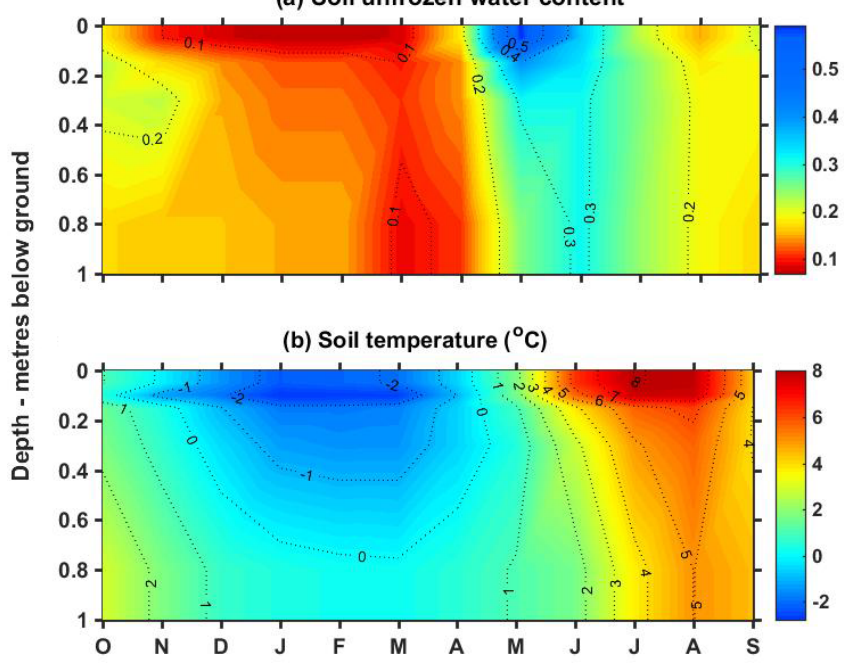

Figure 6. Water year cycle of (a) the unfrozen water content of soil and (b) soil temperature at the shrub tundra site in Wolf Creek Research Basin at depths of 0 to $1 \mathrm{~m}$ below ground surface.

processes in subarctic mountainous environments. The longterm dataset at multiple elevations and land-cover types can be used to examine the variability of hydrometeorological fluxes with elevation and land-cover. As an example, the data have been used to investigate the hydrological influence exerted by shrub tundra (Pomeroy et al., 2006). The unique dataset will be valuable to research communities working on mountain and northern hydrology for various purposes such as hydrological model development, assessment of climate change impacts, and inter-site comparison of hydrological processes. 
Author contributions. KR and TJW cleaned, organized, and corrected the data and wrote the first draft of the paper. JWP, JRJ and SKC designed and built the instrumented research basin, collected data, managed the data collection over the last three decades, and contributed to the writing of the manuscript.

Competing interests. The authors declare that they have no conflict of interest.

Disclaimer. Any reference to specific equipment types or manufacturers is for informational purposes and does not represent a product endorsement.

Special issue statement. This article is part of the special issues "Hydrometeorological data from mountain and alpine research catchments" and "Water, ecosystem, cryosphere, and climate data from the interior of western Canada and other cold regions". It is not associated with a conference.

Acknowledgements. The authors wish to acknowledge three decades of Wolf Creek Research Basin operation, with substantial contributions to installation, maintenance, and operation of the core snow surveys, meteorological stations and hydrometric stations under inclement conditions from Glenn Ford, Glen Carpenter, Kerry Paslowski, Martin Jasek, Dell Bayne, Newell Hedstrom, Raoul Granger, Cuyler Onclin, Michael Solohub, and Richard Essery amongst many others. Funding for the basin has come from Yukon Environment, Environment Canada, DIAND, NSERC, CFCAS, NERC, Welsh Assembly Government, NOAA, and other sources. The research was funded by the NSERC's Discovery Grants and Post-doctoral Fellowship, the Changing Cold Regions Network, the Alexander Graham Bell Canada Graduate Scholarship-Doctoral Program and Global Water Futures. This paper is dedicated to the late J. Richard Janowicz, whose dream of a northern research basin was realised in Wolf Creek Research Basin; a dream to which he tenaciously devoted the last 27 years of his life.

Edited by: Danny Marks

Reviewed by: two anonymous referees

\section{References}

Carey, S. K., Quinton, W. L., and Goeller, N. T.: Field and laboratory estimates of pore size properties and hydraulic characteristics for subarctic organic soils, Hydrol. Process., 21, 2560-2571, 2007.

Dornes, P. F., Pomeroy, J. W., Pietroniro, A., Carey, S. K., and Quinton W. L.: Influence of landscape aggregation in modelling snowcover ablation and snowmelt runoff in a sub-arctic mountainous environment, Hydrolog. Sci. J., 53, 725-740, 2008.

Francis, S., S. Smith, and Janowicz, R.: Data integration and ecological zonation of Wolf Creek watershed. Wolf Creek Research Basin-Hydrology, Ecology, Environment - Proceedings of a workshop held in Whitehorse, Yukon, 5-7 March 1998, edited by: Pomeroy, J. W. and Granger R. J., Citeseer, 93-100, 1998.

Goodison, B., Louie, P., and Yang D.: The WMO solid precipitation measurement intercomparison, World Meteorological Organization-Publications-WMO TD, World Meteorological Organization, Geneva, Switzerland, 65-70, 1998.

Harder, P. and Pomeroy, J.: Estimating precipitation phase using a psychrometric energy balance method, Hydrol. Process., 27, 1901-1914, 2013.

Klemeš, V.: The modelling of mountain hydrology: the ultimate challenge, IAHS-AISH publication, Hydrology of Mountainous Areas, Proceedings of the Strbské Pleso Workshop, Czechoslovakia, June 1988, 190, 29-43, 1990.

Kochendorfer, J., Nitu, R., Wolff, M., Mekis, E., Rasmussen, R., Baker, B., Earle, M. E., Reverdin, A., Wong, K., Smith, C. D., Yang, D., Roulet, Y.-A., Buisan, S., Laine, T., Lee, G., Aceituno, J. L. C., Alastrué, J., Isaksen, K., Meyers, T., Brækkan, R., Landolt, S., Jachcik, A., and Poikonen, A.: Analysis of singleAlter-shielded and unshielded measurements of mixed and solid precipitation from WMO-SPICE, Hydrol. Earth Syst. Sci., 21, 3525-3542, https://doi.org/10.5194/hess-21-3525-2017, 2017.

Laudon H., Spence, C., Buttle, J., Carey, S. K., McDonnell, J. J., McNamara, J. P., Soulsby, C., and Tetzlaff, D.: Saving northern high-latitude catchments, Nat. Geosci., 10, 324-325, https://doi.org/10.1038/ngeo2947, 2017.

Lewkowicz, A. G. and Ednie M.: Probability mapping of mountain permafrost using the BTS method, Wolf Creek, Yukon Territory, Canada, Permafrost Periglac., 15, 67-80, 2004.

MacDonald, J. P.: Unloading of intercepted snow in conifer forests, MSc Thesis, University of Saskatchewan, Saskatoon, Canada, 93 pp., 2010.

McCartney, S. E., Carey, S. K., and Pomeroy, J. W.: Intra-basin variability of snowmelt water balance calculations in a subarctic catchment, Hydrol. Process., 20, 1001-1016, 2006.

Pan, X., Yang, D., Li, Y., Barr, A., Helgason, W., Hayashi, M., Marsh, P., Pomeroy, J., and Janowicz, R. J.: Bias corrections of precipitation measurements across experimental sites in different ecoclimatic regions of western Canada, The Cryosphere, 10, 2347-2360, https://doi.org/10.5194/tc-10-2347-2016, 2016.

Pomeroy, J. W. and Granger, R. J.: Wolf Creek Research Basin: Hydrology, Ecology, Environment. National Water Research Institute, Environment Canada, Saskatoon, Saskatchewan, Canada, 160 pp., 1999.

Pomeroy, J. W. and Gray, D. M.: Snow accumulation, relocation and management, National Hydrology Research Institute Science Report, no. 7, Environment Canada, Saskatoon, Canada, 144 pp., 1995.

Pomeroy, J. W., Marsh, P., and Gray, D. M.: Application of a distributed blowing snow model to the Arctic, Hydrol. Process., 11, 1451-1464, 1997.

Pomeroy, J. W., Hedstrom, N., and Parviainen, J.: The snow mass balance of Wolf Creek, Yukon: effects of snow sublimation and redistribution. Wolf Creek Research Basin-Hydrology, Ecology, Environment - Proceedings of a workshop held in Whitehorse, Yukon, 5-7 March 1998, edited by: Pomeroy, J. W. and Granger R. J., 15-30, 1998.

Pomeroy, J. W., Toth, B., Granger, R. J., Hedstrom, N. R., and Essery, R. L. H.: Variation in surface energetics during snowmelt in 
a subarctic mountain catchment, J. Hydrometeorol., 4, 702-719, 2003.

Pomeroy, J. W., Bewley, D. S., Essery, R. L. H., Hedstrom, N. R., Link, T., Granger, R. J., Sicart, J. E., Ellis, C. R., and Janowicz J. R.: Shrub tundra snowmelt, Hydrol. Process., 20, 923-941, 2006.

Quinton, W. L. and Carey, S. K.: Towards an energy-based runoff generation theory for tundra landscapes, Hydrol. Process., 22, 4649-4653, 2008.

Rasouli, K.: Sensitivity analysis of mountain hydrology to changing climate, $\mathrm{PhD}$ thesis, University of Saskatchewan, Saskatoon, Canada, 251 pp., 2017.
Rasouli, K., Pomeroy, J. W., Janowicz, J. R., Carey, S. K., and Williams, T. J.: Hydrological sensitivity of a northern mountain basin to climate change, Hydrol. Process., 28, 4191-4208, 2014.

Rasouli, K., Pomeroy, J. W., Janowicz, J. R., Williams, T. J., and Carey, S. K.: Hydrometeorological data collected at Wolf Creek Research Basin, Yukon Territory, Canada over 1993-2014, Federated Research Data Repository, https://doi.org/10.20383/101.0113, 2018.

Rasouli, K., Pomeroy, J. W., and Whitfield P. H.: Hydrological response of headwater basins to perturbed climate in North American Cordillera, J. Hydrometeorol., revised and resubmitted, 2019. 